\title{
INTEGRATED WATER MANAGEMENT
}

\author{
Warren Viessman, Jr. \\ Associate Dean of Engineering \\ University of Florida
}

\section{INTRODUCTION}

In recent years the "watershed" has again become the focal point for water resources management strategies, but the idea is certainly not new. Numerous reports have been written on the subject (Viessman and Welty, 1985). Many of them reveal the fact that we have yet to find the key to broadly conceptualizing and implementing integrated water management plans. A good example is the "landmark" National Water Commission (NWC) report, "Water Policies For The Future" (NWC, 1973). That report, and many that have followed it, suggest that for the future, a more holistic approach to water management is needed.

\section{INTEGRATED WATER MANAGEMENT}

Integrated water management means putting all of the the pieces together. Social, environmental and technical aspects must be considered. Issues of concern include: providing the forums; reshaping planning processes; coordinating land and water resources management; recognizing water source and water quality linkages; establishing protocols for integrated watershed management; addressing institutional challenges; protecting and restoring natural systems; reformulating existing projects; capturing society's views; articulating risk; educating and communicating; uniting technology and public policy; forming partnerships; and emphasizing preventive measures. The challenge is to guide water management decision-making into flexible, holistic, and environmentally sound directions (Ballweber, 1995; Bulkley, 1995; Deyle, 1995; Viessman and Welty, 1985). Water resources professionals must be prepared to offer credible guidance to those who need it, at the right time, and in a comprehensible form. The Universities Council on Water Resources (UCOWR) and the university community are ideally suited to assist in that role.

\section{Providing the Right Forums}

Effective forums for designing implementable water management policies and programs must be arranged. In some cases, existing arenas are adequate (city councils, state legislatures, special interest group committees) but these do not always bring the major stakeholders to the table. Two types of forums are needed: those related to resolving or avoiding conflicts (consent building), and those related to solving problems that transcend normal political and/or agency boundaries (system-encompassing). The first type of forum is needed to address points of contention, whereas the second is needed to analyze issues in their proper spatial and/or institutional context. Historically, little has been done to organize such forums, or to use them effectively, but there is evidence that their use in water resources planning and management processes is increasing (Viessman and Welty, 1985, Sheer, 1989).

\section{$\underline{\text { Improving Planning Processes }}$}

Some changes in planning processes will be needed if water resources are to be managed in an integrated manner. Plans have ranged from lists of projects or programs that a constituency desires to have implemented, to comprehensive blueprints for action to meet targeted goals. A 1985 survey of state water planning programs in the U. S. identified some of the shortcomings in planning efforts and indicated that integrated water resources planning was more conceptual than actual (Viessman and Biery-Hamilton 1986). The report disclosed that:

- most states had addressed plan implementation, but few had a system that guaranteed that this would occur; - all states had some type of public participation element, but only a few had developed broadly effective approaches; 
only a few states had comprehensive, continuing water resources assessment processes;

concerns about groundwater quality had prompted many states to develop groundwater management policies; only in rare instances had states effectively integrated water quality and water quantity planning;

most state water plans did not have identifiable regional provisions, although a trend toward considering subbasins or sub-regions as viable management units appeared to be emerging; and

- very few states had addressed the issue of consistency of water resources plans among the various levels of government.

Many of the weaknesses pointed out in that study still remain uncorrected. But one of the lessons learned is that water management plans must be proactive. They must be pace-setters in affecting water management decisions. A model planning process should typically: recognize and address society's goals; identify and confront the "right" problems; function effectively within prevailing legal/institutional frameworks; accommodate both short- and long-range scenarios; generate a diverse menu of alternatives; take into account the allocation of water for all needs, including those of natural systems; be stakeholder-driven; take a global perspective; be flexible and adaptable; drive regulatory processes; be the basis for policy-making; foster coordination among planning partners and consistency among related plans; be accommodating of multiple objectives; be a synthesizer; recognize and deal with conflicts; and produce implementable recommendations.

Unfortunately, the adoption of such models has been hampered by the separation of planning and implementing authorities, turf-protection attitudes, short-sighted focusing of efforts, lack of objectivity on the part of planners, and inadequate funding. These deficiencies must be addressed if integrated water management is to be more than a conceptual dream.

\section{Coordinating Land and Water Resources Management}

Water management affects related lands, and land use practices affect related waters. Reservoir developments change land use patterns for better or worse; management of solid wastes may affect water quality; land treatment residues appear in runoff waters; channelizing streams affects their flood plains and wetlan ds; watershed management practices may affect the amount and quality of water available for use; attitudes of landowners are reflected in the impacts they may have on water quantity and/or quality; and facilities siting can disrupt local hydrological regimes. These examples of ties between land-water management practices underscore the need to coordinate water resources planning and management with land use planning and regulation. The importance of this has long been recognized, but overcoming the institutional barriers to it has lagged (NWC, 1973). Creative exercise of land use control powers, such as zoning, could however, go a long way toward mitigating this problem.

Improved coordination among the governments and agencies engaged in land-water management is needed (Viessman and Welty, 1985). In general, there is no pervasive mandate or organizational arrangement that provides for these elements. Planners and managers should be sensitive to the impacts their proposals may have on other governments, agencies, and programs, but there are few formal structures for requiring this. Viewing problems in all of their dimensions is crucial to effective resource management, and yet we continue to operate principally along strict disciplinary, subject-matter, and agency lines.

The public's desire for optimal use of its lands and water resources is not being reflected consistently in the reality of agency, or agency approved plans and their implementing actions. Legal reforms are needed to accomplish this task. Even when fragile lands, such as wetlands, are in state ownership and subject to public trust rights, damages from developmental activities such as drainage sometimes occur. Usually this is due to poor record keeping on ownership, lack of coordination of agency programs, and narrowly-defined planning processes.

\section{Water Source and Water Quality Linkages}

Although water quality and water quantity (surface water and groundwater sources) are inextricably linked, these subjects have been treated too-long as if they were independent. Water quality deserves attention because of its 
implications for affecting the public health, the economy and the quality of ecosystems. And even with large federal investments in pollution control since 1972, the nation's waters continue to be damaged by pollution and misuse. Pollutants reach water bodies from point and nonpoint sources. Of special importance are the vestiges of toxic and hazardous materials disposal that are transported by surface and ground waters.

Hydrologists have long understood that many of the nation's surface water and groundwater systems are physically linked. Unfortunately, development and management of these water sources is commonly undertaken as if they were unrelated. Until recent times, few water rights laws and regulations recognized the interdependencies of these systems and this has exacerbated the compartmentalization which exists. Ideally, where it is feasible, surface water and groundwater systems should be operated jointly, (aquifer storage and recovery systems, for example) to take advantage of the specific attributes of each system. A functional conjunctive use system is exemplified by the Los Angeles Coastal Plain in California (California Department of Water Resources, 1968). In the future, groundwater and surface water resources must be managed holistically, with due consideration given to water quality aspects. Groundwater management must take into consideration: protecting the quality of the resource from degradation by human activities; regulating land use to protect recharge areas; exploring options for artificial recharge and conjunctive use; and establishing sustainable depletion rates for aquifers.

\section{Taking An Integrated Watershed Management Focus}

It is time for water management to take on new dimensions. Agencies must begin to adopt holistic problem-solving approaches to planning and management. More emphasis must be placed on regional and watershed planning and management, and special institutions to accommodate this must be devised. In particular, the public must be acquainted with the efficiencies to be gained by taking a holistic view. Stakeholders should be identifiers of options rather than reactors to them.

Many water management problems cannot be solved in the context of traditional governmental boundaries. The Viessman and Biery- Hamilton study disclosed that about half of the states in the U. S. had considered regional water management approaches by 1985, and that many had plans for some type of regional water management institution. Two states, Nebraska and Florida, have established a form of management district that has broad powers to manage water resources and provide facilities. The twenty-three Nebraska Natural Resources Districts and the five Florida Water Management Districts blanket their states and have similar powers including the authority to levy property taxes (Kovar 1987, Viessman and Welty 1985, Viessman and Biery-Hamilton 1986). Such districts could serve as institutional models for others.

According to Wise, a watershed management approach should be based on a flexible framework that specifies the guidelines, sets forth the roles and responsibilities of key players, and permits the unique attributes of the watershed to dictate appropriate actions (Wise and Pawlukiewicz, 1996). This is analogous to an ecosystems approach in that it considers the linkages between air, water, land, and the life-forms resident within the system's boundaries. Wise identifies three primary attributes: a geographic (watershed) focus; action driven by environmental objectives, solid science, and good data; and partnerships among the key stakeholders. Such an approach suggests that the watershed community will play a meaningful role in the management of its resources.

A conceptual model of watershed management has been proposed by Hall (Hall, 1996). It embraces both natural and human-driven influences on the water cycle. The integrating features of the model are dependent upon:

- basing water management programs on comprehensive, coordinated basin-wide plans and priorities;

- inverting the historical model of fragmented "top down" planning and management;

- recasting the water management roles of federal, state, and local governments and stakeholders, by placing much more of the responsibility for, and the cost of managing this resource at the local level;

assuring a more equitable distribution of the resource;

redefining priorities;

working with nature; 
giving a new emphasis to conservation and reuse; and

adopting and adhering to the ideals of "sustainable development."

Hall suggests that to make the model work, a "Command and Control Team" should be established to lead a debate on watershed issues such as: What futures seem most probable? Which of these is sustainable? Which of these sustainable futures is most desirable? and How can that future be realized?

Moreau comments that integrated watershed management is predicated on principles that are the outgrowth of past water resources and water quality policy planning practices (Moreau, 1996). He states that among the guiding principles are those that specify that watershed management practices should be designed to:

- use integrated hydrologic units such as watersheds or river basins as spatial units for planning;

- plan comprehensively, consider all potential water use allocations, and exploit multiple use options;

- integrate planning for water and related land and ecological resources; and

formulate and evaluate plans consistent with standards and criteria that recognize economic efficiency, environmental quality, and relevant social objectives.

\section{Addressing Institutional Challenges}

Bringing about institutional change is complex, tedious and painful. The philosophies of agencies, the rules of law, and social customs are entrenched and resist modification. Improvements in coordination, collaboration, and consistency among governments and agencies are needed. It must be recognized that what is considered best at one level is not necessarily the best at another. Plans for action should be developed in recognition of these differences. An important planning/management role is that of viewing problems in their full spatial and institutional dimensions.

Workable regional, international, and global water management institutions must be designed and put into operation. Cities, counties, states, and even nations, are often too limited in jurisdiction to deal appropriately with water/environment issues that transcend their boundaries. More often then not, locally perceived problems have regional, if not global, dimensions, and they must be dealt with in that context. The Florida Water Management Districts and the Nebraska Natural Resource Districts are examples of regional institutions that work. There will have to be international acceptance of rules of conduct that go well beyond simple agreements on pollution control. A broad understanding of the functioning of entire ecosystems must become the basis for unified action. And the institutions to do the job can vary from regional authorities with broad powers to international cooperative agreements among nations. There is no uniformly acceptable format, what works well under one circumstance might not work under another. Providing flexibility in institutional design is an imperative.

\section{Protecting and Restoring Natural Systems}

There is widespread concern about protecting, enhancing, and/or restoring natural systems. But the scientific knowledge needed to understand the role these systems play in the balance of nature is limited. Dealing with such issues requires special policies, a good data base, and a high degree of inter-governmental and inter-agency coordination. The nation's of the world are facing increasingly tough decisions regarding the protection of natural systems and the tradeoffs that must be made in order to accomplish this. It is imperative, therefore, that the economic and social impacts of proposed environmental policies be understood. This means that considerable effort must be placed on understanding the interactions inherent in ecosystem functioning. If we do not know how these systems work, we cannot estimate the consequences of proposed actions. Development and environmental protection can be partners, but only if care is exercised in modifying the landscape. Growth management policies that embrace the many dimensions that must be dealt with in managing natural systems are badly needed.

The restoration of some structurally-modified systems to a condition more nearly resembling that of their original undeveloped state is becoming common as a goal of society. The challenge is to maintain a focus on sustainable 
development while at the same exploring options for repairing environmental damage. Environmental restoration requires an understanding of the functioning of ecosystems that stresses the limits of scientific knowledge. Care must also be exercised to insure that restoration schemes do not create other impacts that may be as negative as those expected to be corrected. In Florida, restoration projects for the Kissimmee River and the Everglades are excellent examples of contemporary approaches to environmental systems recovery (South Florida Water management District, 1994).

Protocols for making tra deoffs and establishing relative values for making water allocation decisions for environmental purposes are also needed. Casting the value of a constructed waterway in monetary terms is relatively easy to do, but when it comes to establishing a value for a wetlands, a natural habitat, or an instream flow to support fish and wildlife, problems abound. This is a critical issue. Economic measures, weights, qualitative indexes, contingent valuation techniques, and other approaches must be considered. This is a subject still in need of research.

\section{$\underline{\text { Reformulating Existing Projects }}$}

Numerous water projects have been built since the turn of the century. Many of these were originally designed for a single purpose, or for specific multiple purposes. Today, some of the original purposes may no longer be valid, or may not require the same level of attention they deserved in the past. It is often possible to change the operating policies for these projects so that they are more accommodating of contemporary needs. Such practices can result in water use efficiencies, cost savings and minimization of new project construction.

\section{$\underline{\text { Capturing Society's Views }}$}

Water management plans should be proactive and designed to influence policy. They must embody social goals, and hence capture public views and perceptions at the outset. Sources of conflict should be identified early-on so that options for managing them can be defined before strong adversarial stances emerge. Planning is for people, and it is their vision of the future that must be captured. They, not the planners should set the specifications. Furthermore, the public should be used as a sounding board for suggesting reformulations of existing water projects and programs.

\section{$\underline{\text { Articulating Risk }}$}

One of the most troublesome issues facing decision-makers is that of dealing with risk. The quantification of risk, the perception of risk, and the level of risk to be accepted by society are all subjects which must be dealt with (Keith 1986, Waterstone and Lord, 1989). Unfortunately, there are not many good models for risk communication to the public. There is a great need for education on the part of both those who understand the likelihood of danger and those who only perceive that danger. Scientists are not omnipotent. And they are often not able to converse adequately with the public or to deal with emotion rather than reason. The policy maker, on the other hand, must be able to operate in an arena of uncertainty and public fear, and at the same time bring some rationality into judgments about levels of risk to accept. There is a need for targeted risk assessments and risk benefit analyses. And the public view must be included, up-front, in policy designs where risk and uncertainty are issues. The costs and benefits of reducing risk must be more clearly articulated.

\section{Educating and Communicating}

Education and communication are keys to shaping water policy. It is important for the public to become more conversant with the water-environment agenda, its roots, and its links to other issues of concern to society. Adult, public, and professional education programs that deal with water issues should be expanded. And agencies, interest groups, and others could establish centers to communicate relevant scientific and technical information. Basin-wide or regional workshops and/or conferences could be held to acquaint citizens with the true dimensions of water management problems and to identify potential courses of action. 


\section{Uniting Technology and Public Policy}

The technologic capability for addressing water management problems is staggering. But exploitation of its potential is constrained by our inability to apply it with in the realities of political and social systems. Scientific and technical understanding should be united with the goals of society. Optimal technical approaches may be socially unacceptable, and compromises often have to be struck. These agreements must be based on a blending of technical options with the public's view of what it deems to be an acceptable solution to the problem at hand. Technicians must take steps to ensure that the public view is understood and incorporated in their designs. And while technology is only one of many factors affecting water resources decision-making, it is ubiquitous in that it permeates planning, policy-making, regulatory, design, and implementation processes.

\section{$\underline{\text { Forming Partnerships }}$}

There is a need for federal and state agencies and other institutions to strengthen and/or establish partnerships among themselves and with relevant publics. Such cooperative arrangements aid in conflict resolution, enhance efficiency in commitment of resources, and facilitate the identification of paths that complement and/or supplement each other's goals. This approach fosters learning from, rather than opposing, one another. Partnering is one way to bring about needed institutional reforms.

Partnering means much more than forming a reactive panel of those who might be affected by a proposed course of action. It means effectively integrating stakeholder views and attitudes into planning and management processes. It must be recognized, however, that the missions, legislative mandates, and administrative policies among partners may be very different. Differences in view must be identified and accepted, and commonalities in interest sought as the building blocks for consensus. The goal should be to ensure that there are no real losers, that all receive some spoils in pursuing a common target. But partners must recognize that tradeoffs must be made to improve the collective whole. Finally, a necessary condition for establishing mutual trust is that partnering arrangements be open, frank and honest. Unless that condition is met, there will be little incentive for meaningful cooperation.

Partners should be involved in planning and decision making processes from the outset. A total commitment is needed. Addressing the views of each partner in a joint forum aids in overcoming inequities and can preempt objections that might be raised in a more adversarial forum if involvement occurs too late. By allowing all to participate in decision making processes freely, and in a timely manner, tensions are likely to be reduced, and agreement on a common ground for closure regarding the issues of concern reached.

Essential elements of partnership building are: establishing the need for the partnership and agreeing upon a common set of goals; identifying and involving the key stakeholder groups/individuals; getting agreement that closure of the issue of concern is an expected outcome of the partnership; providing the right forum(s) for partner participation; obtaining the direct involvement and support of partner leaders; embracing a holistic view of the problem and its solution; and establishing an equal playing field for every partner.

\section{$\underline{\text { Focusing on Preventive Measures }}$}

In the future, we must give more attention to preventive rather than remedial approaches to solving some of our water problems. In the long-run, considerable savings in costs and reduction in environmental degradation can be expected. The old adage "an ounce of prevention is worth a pound of cure" is appropriate, and planning processes should be modified to take this focus.

\section{CONSTRAINTS TO BE DEALT WITH}

Integrated water management is conceptually sound. It should certainly be the goal, and if at all possible, the practice. Conceptualization, however, is easier to accomplish than implementation. The more comprehensive the management 
approach, the more tortuous the path. There are a host of barriers that must be overcome if we are to successfully engage in truly integrated watershed development and management. Roadblocks include:

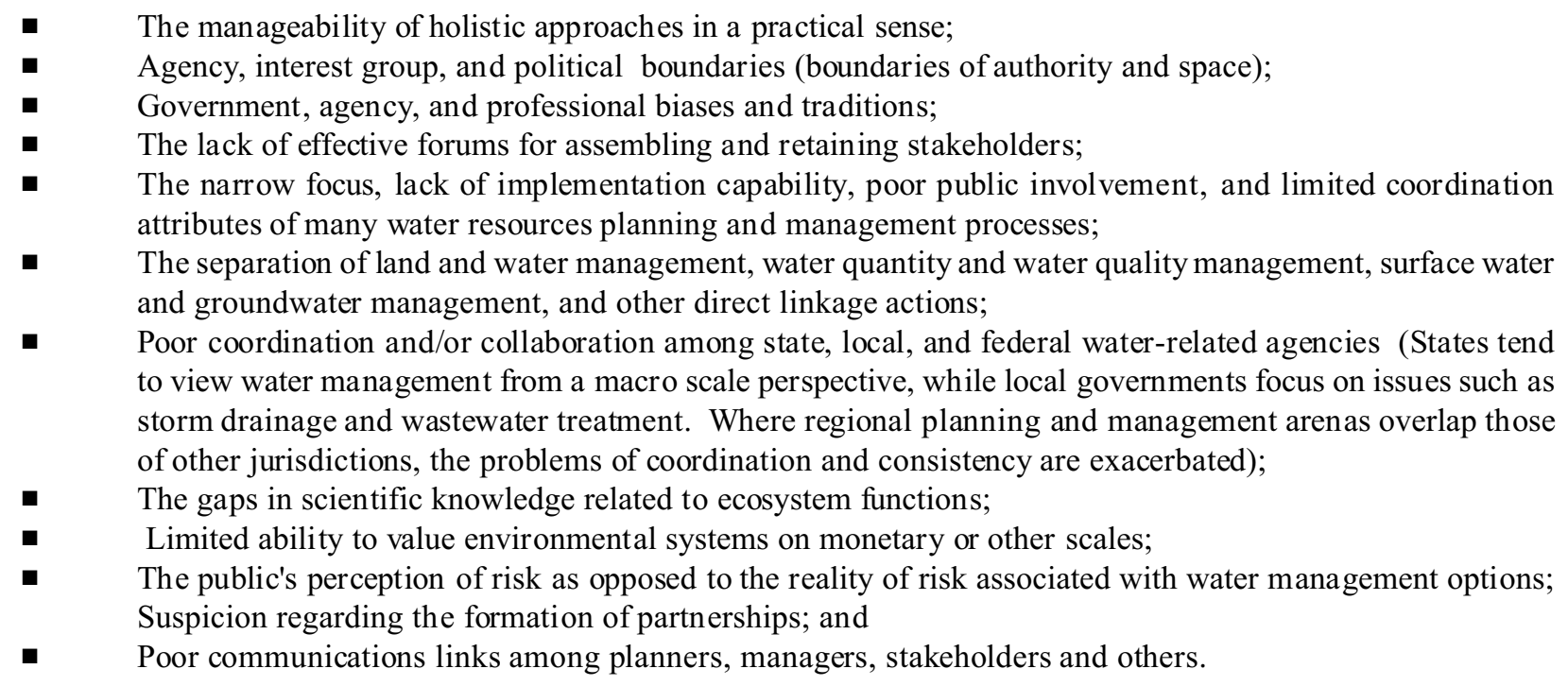

\section{THE ROLE OF UNIVERSITIES IN FOSTERING INTEGRATED WATER MANAGEMENT}

Decisions are based on information. It may be the arguments of a special interest group, an emotion aroused by a created scenario, an objective analysis of an issue by some credible party, or something else. Those making decisions all have a stake in the issue with which they are confronted, but the nature of their decision can, and often is, affected by external input to the knowledge base during the decision-making process. Social scientists, engineers, and others should be committed to providing the best information available on all aspects of the issues being deliberated. The objective should be to inform both those influencing decisions (the public) and those making the decisions (the political bodies). This is a simple notion, yet it is vital to good water management and should not be taken for granted. It is regrettable when we do not have adequate knowledge of the complex social-technological-environmental systems with which we must deal, but it is inexcusable for us to sanction decisions on issues about which information exists, or can be generated, but is not conveyed.

Information transfer and education are partners. Informing the public, decision-making bodies, and others begins with their education as children. The better informed on water-related issues our citizens are, the more likely they are to demand quality decisions by their elected representatives. Furthermore, the better informed the decision maker, the more likely he/she is to make good choices. Material on water-environment issues should be introduced into the curricula for grades $\mathrm{K}$ through 12. More emphasis should be placed on courses dealing with water issues in programs for adult, public, and professional education. And college courses and curricula dealing with water and environmental management should be expanded to include their total dimensions -- legal, social, political, technical, and environmental.

The university community and UCOWR have an important role to play in the development and implementation of strategies for integrated water management. The primary roles of the universities are teaching, research, and service. These assignments are germane to the water management issue, for they all serve to provide an information base and to educate a variety of publics.

Teaching

There are many opportunities for the UCOWR community (university faculty) to foster and encourage education and research programs designed to prepare college students, the public, and K-12 children to influence water management policies. Universities can: 
- Promote and support undergraduate and graduate programs which include instruction in the procedures for, and the importance of, involvement of scientists, engineers, social scientists and other professionals in decision-making processes. Such concepts should be embodied in technical courses as well as in courses on topics such as public policy, economics, dispute resolution, and management science.

- Sponsor continuing education programs to help practitioners keep their state-of-the-art edge.

- Hold seminars, symposia, and conferences on contemporary water-related topics.

- Promote the publication of articles, reports, and books which address designing and implementing integrated water management policies. White papers and pro-con analyses on subjects of current interest to policy makers, administrators, and the public can be very useful. Such papers must be objective, technically sound, and understandable, however, if administrators, legislators and other targets are to make use of them.

- Foster the importance of objectivity which professional judgement should bring to the table. That is what is needed now. Unfortunately, objectivity has diminished with political and social pressures. An easy route has been taken, but it is one with potentially grave consequences for the future. Abel Wolman' once stated that "... one can discern a long, evolving manifestation of intimidation of professional objectivity ..." this says it very well. Needed are mechanisms by which objectivity can be brought into decision-making processes in an effective manner.

Education is the key to what the future holds. Given that water managers must be able to function effectively in political, social, and technological environments, we must prepare students to present well-informed choices, ones that are politically feasible, socially acceptable, and technically and economically sound. Students must be taught the art of problem solving in the context of constraining environmental, social, and political influences. They must learn to objectively assess options and know how to present their findings so that those without technical expertise can understand and use them.

\section{$\underline{\text { Research }}$}

Long-lasting solutions to many of the toughest water problems facing the planet earth will be realized only if they are supported by on-target, competent research. For example, the cooperative water management program developed for the Potomac River Basin would never have come about if it had not been for research that proved that the proposed operating policy could save construction costs and result in added availability of water during low-flow periods (Viessman, 1984). Research is needed on many issues such as the health effects of various constituents in drinking water, the handling of solid and hazardous wastes, economic approaches to wastewater renovation, groundwater quality protection, ecosystem protection and management, environmental restoration, valuing environmental systems, and others. But the research, if it is to be of value, must be responsive to the needs of society, and researchers must be ready to demonstrate how their technical achievements can be applied to practical advantage by those who must plan, design, construct, operate, maintain, and manage the global water infrastructures. The universities, through their water research centers and other institutions, can be a major force in formulating new directions for water management, but to do this, they must be mindful of what is really needed, and minimize the focus on self-serving projects of narrow investigator interest. UCOWR can:

- Encourage research directed toward linking the technical dimensions of mathematical modeling of water resources systems with interactive computerized systems which decision-makers can use to evaluate the consequences of their decisions in terms they can understand.

Aid in designing approaches which effectively translate research findings into formats suitable for use by decision-making bodies. 
- Support case studies which suggest new and/or improved management options. The tools of diagnosis and evaluation at our disposal permit prompt, in-depth evaluations of many courses of action. It is time we started to objectively examine the systems already in place to see if they can be operated more efficiently, and if so, what changes would be needed to bring this about. But to undertake such efforts, those involved will have to fully understand the total dimensions of these systems -- physical and institutional.

$\underline{\text { Service }}$

There are many service roles that university faculty can play in support of integrated water management. University administrators should encourage their faculty to participate in government by voting; running for elected office (to the extent practical); serving in staff positions for committees of the Congress, State legislatures, and city councils; and serving on governmental and/or agency advisory boards. An awareness of the opportunities for faculty to become effective participants in government should be actively pursued.

Faculty should be encouraged to participate more directly in citizen's groups and meetings. Informing lay persons on topics related to water and environmental management should be routinely practiced. Active membership in special interest groups having a stake in water resources development or management can aid in conflict identification and resolution. Faculty should also be advised of the opportunities they may have to affect water resources goals and objectives through the day-to-day interpretation of regulations and the manner in which these regulations address statutory requirements. Academicians having an understanding of ecosystems management, consent building, technology, public policy and countless other subjects related to integrated water management have an obligation to share their knowledge with the public and with decision-making bodies.

\section{CONCLUSIONS}

Integrated water management is the paradigm for the 21 st century. The true spatial, environmental and institutional, dimensions of problems must be recognized, and they must be dealt with accordingly.

There is a need for improved coordination and collaboration among water resources planning and management agencies. Planning and management contexts must be consistent with the issues they address, and they must recognize relevant ecosystem interactions.

Objective forums are needed to address the true dimensions of water management problems, to bring stakeholders to the table, and to reach a consensus.

Integrated water management plans should drive water resources decision-making processes and serve as the basis for developing regulatory programs.

Educators have an important role to play in the development and implementation of strategies for integrated water management. The teaching, research, and service functions of universities are ideally suited to educate a variety of publics on water management issues.

Water management policies must take on global dimensions. Interagency and intergovernmental coordination, cooperation, and collaboration must be improved. Political processes must be better understood and shaped to focus on holistic land-water management approaches. And preventive, rather than remedial actions should be emphasized. 


\section{REFERENCES}

Ballweber, J. A., "Prospects for Comprehensive, Integrated Watershed Management Under Existing Law," Water Resources Update, Universities Council on Water Resources, Issue No. 100, Summer, 1995, pp. 19-23.

Bulkley, J. W., "Integrated Water Management: Past, Present, and Future," Water Resources Update, Universities Council on Water Resources, Issue No. 100, Summer, 1995, pp. 7-18.

California Department of Water Resources, "Planned Utilization of Ground Water Basin: Coastal Plain of Los Angeles County,” Bull. 104, Sacramento, California, 1968.

Deyle, R.E., "Integrated Water Management: Contending With Garbage Can Decision making In Organized Anarchies," Water Resources Bulletin, American Water Resources Association, Vol. 31, No. 3, June 1995, pp. 387-398.

Hall, M. W., "A Conceptual Model for Integrated Water Management," paper prepared for workshop on "Total Water Environment Management for Military Installations," U. S. Army Environmental Policy Institute, Atlanta, Georgia, 1996.

Keith, S.J., June 1986. "Science/Facts Versus Perception in the Public Decision-Making Process," Ground Water, Vol. 24, No. 3, May-June 1986.

Kovar, A., "Natural Resource Districts And Groundwater Quality Protection: An Evolving Role," in Redefining National Water Policy: New Roles and Directions, edited by Stephen M. Born, Special Publication No. 89-1 of the American Water Resources Association, 1989, pp. 51-72.

Moreau, D. H., "Integrated Water Management at Military Bases: From Principles to Practice," paper prepared for workshop on "Total Water Environment Management for Military Installations," U. S. Army Environmental Policy Institute, Atlanta, Georgia, 1996.

National Water Commission (NWC), Water Policies for the Future, U.S. Gov't. Printing Office, Washington, D.C., June 1973.

Sheer, D.P., "Management of Water Resource Systems," National Forum, Vol. LXIX, No. 1, Winter 1989, pp. 8-10.

South Florida Water Management District, "Everglades, 1994 Annual Report," West Palm Beach, Florida, 1994.

U.S. Congress, Senate Committee On Interior And Insular Affairs, "The Water Resources Planning Act: An Assessment," Committee Print, U.S. Government Printing Office, Washington, D.C., 1975.

Viessman, Jr., W, “Research - A Vital Link in Effective Water Management," in Water Resources in Texas: The Need for A Research Agenda, edited by Ernest T. Smerdon, Water Resources Symposium Number Eleven, Center for Research in Water Resources, University of Texas at Austin, 1984, pp. 23-33.

Viessman, Jr., W and C. Welty, Water Management: Technology And Institutions. Harper and Row Publishers, Inc. New York, New York, 1985.

Viessman, Jr., W and G.M. Biery-Hamilton, “An Analysis Of State Water Resources Planning Processes In The United States," Volume III of Comprehensive Review OfWater Resources Policies, Planning and Programs in Florida, Northwest Florida Water Management District, Havana, Florida, 1986.

Walker, W.R., "Coordinating the Components of an Integrated Water Management Program," paper prepared for workshop on "Total Water Environment Management for Military Installations," U. S. Army Environmental Policy Institute, Atlanta, Georgia, 1996. 
Waterstone, M. and W.B. Lord, "How Safe is Safe," National Forum, Vol. LXIX, No. 1, Winter 1989, pp. 22-25.

Wise, L. P. and J. Pawlukiewicz, "The Watershed Approach: An Institutional Framework for Action," paper prepared for workshop on "Total Water Environment Management for Military Installations," U. S. Army Environmental Policy Institute, Atlanta, Georgia, 1996.

Warren Viessman, Jr. is Associate Dean for Academic Programs in the College of Engineering at the University of Florida. He has held many positions in water-related programs and is widely published. 